Acta Theriologica 38 (2): 175 - 183, 1993.

PL ISSN $0001-7051$

\title{
Reproductive plasticity of the American mink Mustela vison in Belarus
}

\author{
Vadim E. SIDOROVICH
}

\begin{abstract}
Sidorovich V. 1993. Reproductive plasticity of the American mink Mustela vison in Belarus. Acta theriol. 38: 175 - 183.

Reproduction of the American mink Mustela vison Schreber, 1777 population introduced to Belarus was studied in 1983 - 1992. Material consisted of 52 male genitalia, carcasses of 45 pregnant females, and observations of 19 litters with blind cubs and 31 litters with larger cubs. The study was conducted in two areas in northern Belarus: Rossony, where the decrease of mink numbers due to excessive trapping was recorded, and Gorodok, where the expansion of American mink in the presence of the native European mink Mustela lutreola was observed. Mating period of American mink lasted from mid February to mid April. Young were born from April till mid June. Litter size was on average 4.2 (blind cubs) and 3.3 in older cubs ( $>2$ months old). Reproduction intensity on Drissa river and its tributaries was related to density. On average, 3.3 embryos per pregnanat female were found in 1 -yr females and 4.3 in $\geq 2$-yr old females at the density of $13.3 \mathrm{mink} / 10 \mathrm{~km}$ of watercourse. In the low density population ( $2.8 \mathrm{mink} / 10 \mathrm{~km}$ due to overexploitation by hunters) reproduction intensity increased to an average of 4.2 embryos in 1 -yr females and 6.0 in $\geq 2$-yr females. During population decrease, percentage of young increased and the sex ratio became biased towards females. In an expanding population of American mink that had newly colonised Lovat river, the reproduction was very intense $(7.3-7.6$ embryos/female $)$. The results show a great reproductive plasticity of American mink that obviously helped this species to successfully colonise new ranges after introduction.
\end{abstract}

Institute of Zoology, Belarusian Academy of Sciences, F. Skorina Street 27, Minsk 220072, Belarus

Key words: Mustela vison, density, reproduction, Belarus

\section{Introduction}

Study of reproduction is an important part of demographic analysis of animal populations and a basis of investigations of species ecology (Yablokov 1986, Begon et al. 1990). An important object of such study is to ascertain the relationships between reproductive parameters and dynamics of population numbers and structure (Soule 1987, Begon et al. 1990). I tried to show these relationships in the American mink Mustela vison Schreber, 1777 which was introduced to Belarus in 1953 - 1958 (Serzhanin 1961). Despite the intense hunting pressure and competition with two native species, the river otter Lutra lutra and European mink Mustela lutreola, the American mink in Belarus increased in numbers from 865 in the late 1950 s (Serzhanin 1961) to c. 56,000 in the late 1980 s (Sidorovich 
1988). During that period, American mink colonised almost entire territory of Belarus, including places located $200-300 \mathrm{~km}$ away from the nearest place of release for introduction.

Numerous researches reported on a great ecological (trophic, demographic, behavioural) plasticity of American mink within its natural range (Mitchell 1961, Gilbert and Nancekivell 1982, Linscombe et al. 1982, Arnold and Fritzell 1987), in the areas of introduction (Gerell 1968, 1971, Erlinge 1972, 1986, Danilov and Tumanov 1976, Poole and Dunstone 1976, Chanin and Linn 1980, Jenkins and Harper 1980, Chanin 1981, 1983, Wise et al. 1981, Pulliainen 1984, Skirnisson 1989, Sidorovich 1991a, b, 1992, Smal 1991), and in captivity (Enders 1952, Venge 1973, Ternovsky 1977, Elofson et al. 1989).

The viability of American mink populations in the areas of introduction, where this species faced new ecological conditions, was based on stable demography. An intense reproduction allowed mink to quickly compensate for the sudden population losses (Mitchell 1961, Gerell 1971, Venge 1973, Linscombe et al. 1982, Chanin 1983, Smal 1991). Studies on captive animals revealed that the reproductive potential and plasticity of mink are relatively high (Enders 1952, Venge 1973, Elofson et al. 1989). However, these aspects of American mink ecology in natural conditions are poorly studied.

The aims of this work were: (1) to characterise the breeding of the free-living American mink in Belarus, (2) to relate the fertility and reproduction parameters to the density changes, and (3) to show how the reproductive plasticity of American mink could have influenced its successful colonisation of new ranges.

\section{Study area}

The study was carried out in two study areas located $100 \mathrm{~km}$ apart in northern Belarus. In 1986 - 1992, demography of American mink was investigated on Lovat river in Gorodok district of Vitebsk region (Gorodok study area, $56^{\circ} \mathrm{N}, 32^{\circ} \mathrm{E}$ ). The field work was conducted on a $60-\mathrm{km}$ stretch characterized by moderate flow (c. $0.4 \mathrm{~m} / \mathrm{s}$ ), relatively full-flowing river bed (mean width $20 \mathrm{~m}$, mean depth $1.2 \mathrm{~m})$ and moderately swamped flood-plains $(20-70 \%)$.

In 1983 - 1992, the study was also conducted in Rossony study area (Rossony, Polotsk, and Verkhnedvinsk districts of Vitebsk region, $56^{\circ} \mathrm{N}, 30^{\circ} \mathrm{E}$ ). The field work was carried out on a $100-\mathrm{km}$ stretch of Drissa river and a $60-\mathrm{km}$ stretch of its tributary, Nishcha river, as well as on Okhonka river, tributary of Nishcha $(18 \mathrm{~km})$ and Marinets, tributary of Drissa $(12 \mathrm{~km})$. Drissa and Nisincha rivers have moderate or high flow-speed $(0.3-0.7 \mathrm{~m} / \mathrm{s})$, relatively full-flowing river-bed $(20-40 \mathrm{~m}$ width and $1.2-2.5 \mathrm{~m}$ deep). Flood-plains often absent, high riverside slopes often forested.

The two study areas were similar in respect of landscape structure, food resources, and habitat conditions for mink populations. European mink Mustela lutreola was practically extinct in Rossony area, whereas it still persisted on Lovat river. American mink appeared in Rossony in the early 1970s. In 1983 - 1988, its population was well established and numbers were stable. Winters 1988/89 and 1989/90 (very mild and snowless) favoured trapping and illegal hunting. The apparently greater hunting pressure on mink led to serious decline of their numbers in those years.

On Lovat river American mink was first recorded in 1989. All skulls $(n=7)$ and numerous fur of mink trapped earlier by the local hunters were European mink. 


\section{Material and methods}

In 1983 - 1991, in both Rossony and Gorodok study areas, I collected (by trapping) totally 52 males (for weighing of genitalia) and 45 pregnant females (for counting embryos). Mink trapped by the local hunters in Rossony area $(n=260$ in $1986-1991)$ and Gorodok area $(n=67$ in $1989-1992)$ were used for estimation of age and sex structure of the population in various years. Young animals ( $<1$ year) were determined by the dental canal width and fusion of skull sutures.

During the field work over the entire area of Belarus, I collected the data on 19 litters of blind cubs by checking the abandoned beaver's Castor fiber lodges, where American mink frequently located their breeding dens. Additionally, observations of 31 litters of cubs following the female were collected in 1983 - 1991 .

Estimates of mink densities were done in Rossony study area in 1984 - 1991 by surveying river banks by snow tracking according to the method described by Teplov (1952) and Ternovsky (1973). Surveys were carried on $10-20-\mathrm{km}$ stretches of rivers (each winter from 6 to 15 stretches were censused). Water courses with high densities of mink were surveyed not later than $1-3$ days after the new snow fall. Mink numbers were recalculated per $10 \mathrm{~km}$ of river bed. In Gorodok study area, density of mink was estimated on 3 stretches in 1986 - 1992. During the snow tracking in Rossony, I was able to determine the sex of 396 mink by the position of feaces; urine and hind footprints in the defecation places (according to Teplov 1952, Danilov and Tumanov 1976).

\section{Results}

\section{Reproductive season of the American mink in Belarus}

Mating period of American mink in northern Belarus started in mid February and ended in mid April (Fig. 1). Most of the females trapped in late March - mid April were pregnant. Findings of blind cubs indicated that births started in April

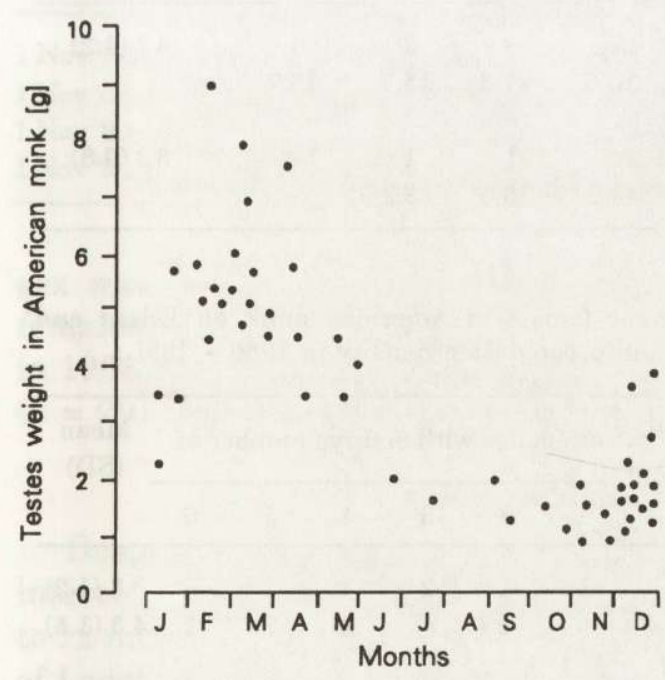

Fig. 1. Seasonal changes in testes mass (with appendages) of American mink (each point $=1$ male) collected in Belarus in $1983-1991$.

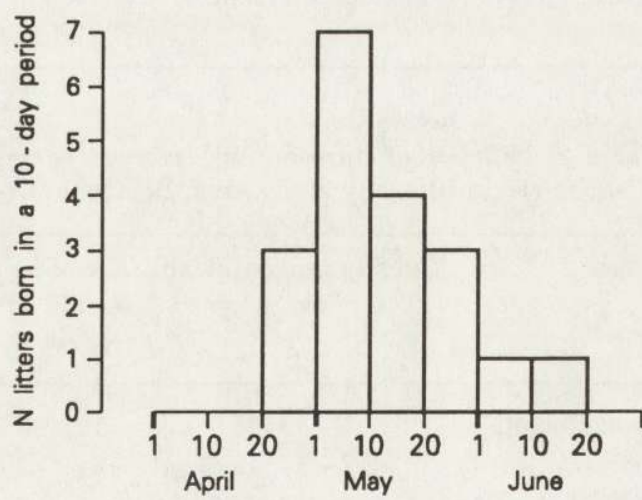

Fig. 2. Seasonal distribution of births in American mink in Belarus. Data from observations of 19 litters of blind cubs. 
and took place until mid June (Fig. 2). Mink used self-prepared burrows or abandoned beaver's lodges as breeding dens.

During the first month after birth, the litter size varied from 2 to 6 (4.2 on average; Table 1). Young mink leave their natal den when 2 months old. Litters of larger young following the females consisted of $2-5$ cubs (3.3 on average (Table 1). Thus, cub mortality during nursing was $21 \%$.

Trapping experience indicates that dispersal of young mink takes place in November. Until about 10th of November, the trap set near the breeding den would consequtively trap few young mink presumably from one litter.

Reproductive capacity of mink in relation to density changes

Data collected in Rossony area allowed the analysis of reproductive capacity of mink in relation to the changes in density due to overexploitation of population by hunters and poachers. In $1986-1988$, the density of mink on Drissa river and its tributaries was $7-18$ animals $/ 10 \mathrm{~km}$ (mean 13.3 ; Table 2 ) and was relatively stable (coefficients of variation on various rivers $5.2-17.9 \%$ ). Otter density on these rivers was low, so it did not seem to be a limiting factor of mink density (Sidorovich 1988). In such a stable population, the fertility of mink ranged from 1 to 5 embryos per pregnant female (mean 3.3 in 1-year-old females and from 2

Table 1. Litter size of American mink (based on observations of females with young) in Belarus in 1983 - 1991.

\begin{tabular}{lcccccccc}
\hline \multirow{2}{*}{ Litter age } & \multicolumn{7}{c}{ Number of young in a litter } & Mean (SD) \\
\cline { 2 - 7 } & & 2 & 3 & 4 & 5 & 6 & \\
\hline Blind cubs (< 1 month) & $n$ & 2 & 2 & 9 & 3 & 3 & $4.2(1.2)$ \\
& $\%$ & 10.5 & 10.5 & 47.3 & 15.7 & 15.7 & \\
Cubs following a female (> 2 months) & $n$ & 5 & 14 & 11 & 1 & - & $3.3(0.8)$ \\
\end{tabular}

Table 2. Number of unresorbing embryos per pregnant female in American mink on Drissa and Nishcha rivers (Rossony study area, Belarus) in relation to population density in $1986-1991$.

\begin{tabular}{|c|c|c|c|c|c|c|c|c|c|c|}
\hline \multirow[t]{2}{*}{ Years } & \multirow{2}{*}{$\begin{array}{l}\text { Density ranges (mean) } \\
n \text { mink } / 10 \mathrm{~km}\end{array}$} & \multirow{2}{*}{$\begin{array}{l}\text { Age of } \\
\text { female } \\
\text { (years) }\end{array}$} & \multirow{2}{*}{$\begin{array}{c}\text { Sample } \\
\text { size }\end{array}$} & \multicolumn{6}{|c|}{$n$ females with embryo number of: } & \multirow{2}{*}{$\begin{array}{l}\text { Mean } \\
\text { (SD) }\end{array}$} \\
\hline & & & & 1 & 2 & 3 & 4 & 5 & 6 & \\
\hline \multirow[t]{2}{*}{$1986-1988 / 89$} & $7-18(13.3)$ & 1 & 8 & 1 & 1 & 2 & 3 & 1 & - & $3.3(1.2)$ \\
\hline & $7-14 \quad(9.8)$ & $2+$ & 6 & - & 1 & - & 2 & 2 & 1 & $4.3(1.5)$ \\
\hline \multirow[t]{2}{*}{$1989 / 90-1990 / 91$} & $3-11(5.0)$ & 1 & 12 & - & 2 & 1 & 4 & 3 & 2 & $4.2(1.0)$ \\
\hline & $1-5(2.8)$ & $2+$ & 8 & - & - & - & - & - & 8 & $6.0(0.0)$ \\
\hline
\end{tabular}


to 6 embryos (mean 4.3) in $\geq 2$-year-old females $\left(U_{\mathrm{s}}=27.5, p>0.1\right.$, Mann-Whitney $U$-test) (Table 2).

After the strong decline of mink numbers (to an average of 2.8 inds $/ 10 \mathrm{~km}$ ) due to overexploitation that took place in $1988 / 89$ - 1989/91, fertility of females raised (Table 2). It ranged from 2 to 6 embryos/female (mean 4.2) in 1-year-old females and was 6 emryos in all $\geq 2$-year-old females $\left(U_{\mathrm{s}}=76, p<0.025\right)$. The increase of fertility was highly significant; it was $27 \%$ in young females $\left(U_{\mathrm{s}}=74, p<0.025\right)$ and $37 \%$ in older females $\left(U_{\mathrm{s}}=44, p<0.005\right)$. It is worth noting that all adult females in low desnity population had 6 unresorbed embryos and one of the females had even the 7 th resorbing one.

Eight of 10 young females and all 6 older females took part in reproduction when density was high. During the decline, all 20 females took part in reproduction.

Changes in age and sex composition of American mink population occurred during the decrease of density. Proportion of young animals $(<1$-year-old) grew from $51-56 \%$ in dense, stable population to $78 \%$ in declining, overexploited population $(G=5.8, \mathrm{df}=1, p<0.025, G$-test for homogeneity of percentages) (Table 3). Among young mink, the sex ratio became significantly biased towards females (Table 3). Similar increase (not significant though) was observed when

Table 3. Changes in sex (F - female, $\mathrm{M}$ - male) and age structure of the declining (due to excessive hunting) population of American mink in Rossony study area in $1986-1991 .^{*} p<0.05,{ }^{* *} p<0.001$ ( $G$-test; deviations from 1:1 ratio). Data from trapped individuals, $n$-number of trapped mink.

\begin{tabular}{lcccccccc}
\hline Period & Winter & $\begin{array}{c}\text { Hunting } \\
\text { pressure }\end{array}$ & $\begin{array}{c}\text { Mean density } \\
\text { mink/10 km }\end{array}$ & $\begin{array}{c}\text { Sample } \\
\text { size }\end{array}$ & $\begin{array}{c}\text { Percent } \\
\text { young }\end{array}$ & $\begin{array}{c}\text { M:F } \\
\text { ratio in } \\
\text { young }\end{array}$ & $\begin{array}{c}\text { Percent } \\
\text { adults }\end{array}$ & $\begin{array}{c}\text { M:F } \\
\text { ratio in } \\
\text { adults }\end{array}$ \\
\hline 1 Nov '86-31 Apr '88 & Cold & Moderate & 13.3 & 100 & 56.0 & $1: 1.1$ & 44.0 & $1: 0.8$ \\
1 Nov'88-31 Apr'89 & Mild & Excessive & 9.8 & 43 & 51.2 & $1: 1.0$ & 48.8 & $1: 0.6^{*}$ \\
1 Nov'89-31 Apr '90 & Mild & Excessive & 5.0 & 71 & 67.6 & $1: 1.3$ & 32.4 & $1: 0.8$ \\
1 Nov'90-31 Apr'91 & Cold & Moderate & 2.8 & 46 & 78.3 & $1: 1.8^{* *}$ & 21.7 & $1: 1.0$ \\
\hline
\end{tabular}

sex was determined in defecation places during the snow tracking: per cent of females in population grew from $43 \%(n=58)$ in $1986-1987 / 88$ to $58 \%(n=298)$ in 1988/89 - 1991, and among embryos: $45 \%$ of females in high density population $(n=20)$ and $60 \%$ in declining population $(n=31)$.

Reproduction of American mink in a newly colonized area

Despite the small sample size, data collected in Gorodok study area were interesting. The combined density of both $M$. lutreola and $M$. vison varied from 5 to $12 \mathrm{inds} / 10 \mathrm{~km}$ in $1990-1992$. These densities were close to the carrying capacity of Lovat river as mink habitat (Sidorovich 1988). American mink was absent from Gorodok study area until 1989. In the hunting season of $1990 / 91$, the skulls $(n=38)$ and furs $(n=44)$ of mink trapped by hunters included $59.7 \%$ of American 
Table 4. Number of embryos per pregnant female American mink in Gorodok study area. ${ }^{1}$ Unresorbing embryos only. ${ }^{2}$ In all females with 9 embryos, one of the embryos was resorbing.

\begin{tabular}{lcccccc}
\hline Year & $\begin{array}{c}\text { Female age } \\
\text { (years) }\end{array}$ & \multicolumn{3}{c}{$n$ females with embryo number of: } & \multirow{2}{*}{$\begin{array}{c}\text { Mean (SD) (whole } \\
\text { sample of the year) }\end{array}$} \\
\cline { 3 - 6 } April 1991 & 1 & 6 & 7 & 8 & 9 & $7.6(0.8)$ \\
& $2+$ & - & - & 2 & $3^{2}$ & \\
April 1992 & 1 & - & 2 & - & - & $7.3(0.6)$ \\
& $2+$ & - & - & 1 & - & \\
\hline
\end{tabular}

mink and $40.3 \%$ of European mink. In 1992, the share of European mink dropped to $19.7 \%$ (of 40 skulls and 26 furs of mink examined).

Among 32 American mink trapped in 1990/91, 12 (37.5\%) were young animals. Female proportion in the total sample was $47 \%$. In 1992, 28 of 35 trapped mink $(80 \%)$ were young; $51.5 \%$ of mink were females. In spring 1991 , fertility was very high and varied from 6 to 8 unresorbing embryos per pregnant female (mean 7.6; Table 4). All trapped females were pregnant. In spring 1992, all 3 trapped females of American mink were pregnant and had 7 or 8 embryos (mean 7.3).

The difference between fertility of American mink in Gorodok and Rossony study areas were highly significant, when the stable, high density population in Rossony was compared to the Gorodok population $\left(U_{\mathrm{s}}=135.5, p<0.001\right)$ and also, when the overexploited, low density population in Rossony was compared to Gorodok population $\left(U_{\mathrm{s}}=227, p<0.001\right)$.

\section{Discussion}

General data on mating and reproduction season of American mink in Belarus conform to the earlier findings on this species in Russia (Danilov and Tumanov 1976, Ternovsky 1977), Scandinavia (Gerell 1971, Elofson et al. 1989, Skirnisson 1989), western Europe (Smal 1991), and North America (Enders 1952). The novel findings of this study are (1) the increase of reproduction intensity in the course of declining numbers due to overexploitation, (2) the sex ratio biased towards females in that declining population, and (3) the greater fertility in an expanding population of American mink.

Population density of mink declines when reproduction does not compensate for the losses. In such situation, observed in Rossony study area, an intensification of reproduction was recorded. All females reproduced every year and their fertility grew. Older females increased their reproduction intensity more $(37 \%)$ than young females (27\%). Higher fertility of older females was recorded by Venge (1973) and Elofson et al. (1989). It is typical for many mammalian species that the medium-aged females are the most productive (Begon et al. 1990). 
The proportion of females among embryos increased, resulting in the growth of reproductive rates. Such mechanisms of intensification of reproduction raise the population fertility. Therefore, excessive hunting pressure on mink during one season should not affect the population seriously, as its density would reestablish quickly. However, the long-lasting excessive hunting caused the bias of age structure towards young animals and reduced the reproductive rates of the population. One-year-old females in such situation were not capable of increasing their reproduction as much as older females did.

Such lowering of population fertility will result in a lowering of numbers. Thus, despite the demographic plasticity of American mink, their capability to compensate for the losses by increased reproduction are limited.

In Gorodok area in 1990 - 1992, the situation of American mink was typical for the expanding population, colonising new area. I suggest the following reconstruction of expansion events. First, single individuals of American mink penetrated into a particular river basin inhabited by European mink. When the density of American mink in a newly occupied range reaches its carrying capacity, the mass occupation of neighbouring territories will occur.

In the presence of competitor (European mink) the reproductive intensity of American mink was so high ( $6-8$ unresorbing embryos/female) that it merely overlapped with that in a well established population in Rossony. High fertility of American mink in Gorodok area allowed this species to successfully occupy the new range. In 1989, American mink appeared here. In 1990 - 1991, its proportion among the two mink species was $60 \%$, and in $1992-80 \%$. I estimate that it would take 2-4 years for the American mink to colonise the Lovat river basin. The entire period of colonisation and establishing a population in a new range (including years when only single animals appear in the area) would be $5-7$ years.

American mink litters with over 6 cubs were recorded several times both in natural and captive conditions (Enders 1952, Venge 1973, Linscombe et al. 1982, Elofson et al. 1989, Skirnisson 1989), but such fertility in natural populations was observed rarely (Gerell 1971, Danilov and Tumanov 1976, Birks and Dunstone 1991). I recorded such high fertility during few years in Rossony study area and in some other areas in Belarus. Obviously, the high fertility in natural conditions is observed during range expansion or during low densities coinciding with very good food supply.

In conclusion, the American mink capability to attain high reproduction rates is a part of a complex reproductive regulation, that allowed this species to maintain viable populations in a highly variable environment and to quickly colonise vast ranges after introduction.

Acknowledgements: I am grateful to Dr A. Tishechkin for translating the text into English and to Drs Z. Pucek and B. Jędrzejewska for their editorial comments. Drs A. Kozulin and S. Saluk helped me in collecting the American mink. 


\section{References}

Arnold T. N. and Fritzell E. K. 1987. Food habit of prairie mink during the waterfowl breeding season. Can. J. Zool. 65: $2322-2423$.

Begon M., Harper J. L. and Townsend C. R. 1990. Ecology: individuals, populations, and communities. Blackwell Scientific Publication, Cambridge: 1 - 945.

Birks J. D. S. and Dunstone N. 1991. Mink (Mustela vison). [In: The handbook of British mammals. G. B. Corbet and S. Harris, eds]. Blackwell Sci. Publ., London: 406-415.

Chanin P. R. F. 1981. The diet of the otter and its relations with the feral mink in two areas of southwest England. Acta theriol. 26: 83 - 95.

Chanin P. R. F. 1983. Observations on two populations of feral mink in Devon, U. K. Mammalia 47: $463-476$.

Chanin P. R. F. and Linn I. J. 1980. The diet of the feral mink (Mustela vison Schreber) in southwest England. J. Zool., Lond. 192: 205 - 223.

Danilov P. I. and Tumanov I. L. 1976. [Mustelids of the north-eastern USSR]. Nauka, Leningrad: 1 - 225. [In Russian]

Elofson L., Lagerkvist G., Gustafsson H. and Einarsson S. 1989. Mating system and reproduction in mink. Acta Agric. scand. 39: 24 - 41.

Enders R. K. 1952. Reproduction in the mink (Mustela vison). Proc. Am. Phil. Soc. 96: 691 - 755.

Erlinge S. 1972. Interspecific relations between otter (Lutra lutra) and mink (Mustela vison). Oikos 23: $327-335$.

Erlinge S. 1986. Specialists and generalists among mustelids. Lutra 29: 5-11.

Gerell R. 1968. Food habits of the mink (Mustela vison Schreb.), in Sweden. Viltrevy 5: $119-211$.

Gerell R. 1971. Population studies on the mink (Mustela vison Schreber) in souther Sweden. Viltrevy 8: $83-114$.

Gilbert F. F. and Nancekivell E. G. 1982. Food habits of mink (Mustela vison) and otter (Lutra canadensis) in northeastern Alberta. Can. J. Zool. 60: 1282 - 1288.

Jenkins D. and Harper R. J. 1980. Ecology of otters in northern Scotland. II. Analyses of otter (Lutra lutra) and mink (Mustela vison) feaces from Deeside, NE Scotland in 1977 - 78. J. Anim. Ecol. 49: $737-754$.

Linscombe G., Kinler N. and Auleirich R. J. 1982. Mink (Mustela vison). [In: Mammals of North America. Biology, management, and economics. J. A. Chapman and G. A. Feldhammer, eds]. J. Hopkins Univ. Press, Baltimore and London: $631-640$.

Mitchell J. L. 1961. Mink movements and populations on a Montana river. J. Wildl. Manage. 25: $48-54$.

Poole T. B. and Dunstone N. 1976. Underwater predatory behaviour of the American mink (Mustela vison). J. Zool., Lond. 178: 395 - 412.

Pulliainen E. 1984. Pohjooissuomen mikkien ravinnon koostumuksesta runsaan pikkujursijakanna oloissa. Suomen Riista 31: $43-46$.

Serzhanin I. N. 1961. [Mammals of Byelorussia]. Nauka i Tekhnika, Minsk: 1 - 315. [In Russian]

Sidorovich V. E. 1988. [Typology of waterbodies as habitats of semi-aquatic carnivores and numbers and densities of their populations in Byelorussia]. Preprint VINITI No. 7935 - V88. Minsk: 1-54. [In Russian]

Sidorovich V. E. 1991a. [Diet and relations of otter (Lutra lutra L.) and American mink (Mustela vison Schreb.) in Byelorussia]. Preprint VINITI No. 1431 - V91. Minsk: 1 - 99. [In Russian]

Sidorovich V. E. 1991b. Distribution and status of minks in Byelorussia. Mustelid and Viverrid Conserv. 5: 14.

Sidorovich V. E. 1992. Comparative analysis of the diets of European mink (Mustela lutreola), American mink (M. vison) and polecat (M. putorius). Small Carnivore Conserv. 6: 2-4.

Skirnisson K. 1989. The reproduction of feral mink in Iceland. XIX IUGB Congr. Poster: $1-4$. 
Smal C. M. 1991. Population studies of feral American mink (Mustela vison) in Ireland. J. Zool., Lond. 224: $233-249$.

Soule M. H. (ed) 1987. Viable populations for conservation. Cambridge University Press., Cambridge: $1-222$.

Teplov V. P. 1952. [Censuses of otter, sable, marten and other small mustelids]. [In: Metody izučenija chislennosti i geograficeskogo rasprostranenija nazemnyh pozvonočnyh]. Nauka, Moscow-Leningrad: $165-172$. [In Russian]

Ternovsky D. V. 1973. [Censuses of Otter and Mink]. Trudy Okskogo Zapovednika 9: 144 - 161. [In Russian]

Ternovsky D. V. 1977. [Biology of mustelids (Mustelidae)]. Nauka, Novosibirsk: 1 - 279. [In Russian]

Venge O. 1973. Reproduction in the mink. Roy. Veterin. and Agric. Univ. Yerabook 1973: 95 - 146.

Wise M. H., Linn I. J. and Kennedy C. R. 1981. A comparison of the feeding biology of mink (Mustela vison) and otter (Lutra lutra). J. Zool., Lond. 195: 181 - 213.

Yablokov A. V. 1986. Population biology. Progress and problems of studies on natural populations. MIR Publishers, Moscow: 1 - 304.

Received 23 December 1991, revised 27 April 1993, accepted 28 April 1993. 